\title{
EKSPRESI HSP 70 DAN EKSPRESI RESEPTOR OPIOID MU PADA PENURUNAN NYERI TERAPI BEKAM BASAH
}

\section{(Expression of HSP 70 and Mu Opioid Receptors Decrease Pain on Wet Cupping Therapy)}

\author{
Imam Subadi ${ }^{*}$, Hening Laswati*, Harjanto $\mathrm{JM}^{* *}$ \\ *Departemen Ilmu Kedokteran Fisik dan Rehabilitasi Fakultas Kedokteran Universitas Airlangga \\ **Departemen Ilmu Faal Fakultas Kedokteran Universitas Airlangga \\ Email: isubadi_roesdam@yahoo.co.id
}

\begin{abstract}
ABSTRAK
Pendahuluan: Terapi bekam basah banyak digunakan untuk mengurangi nyeri, namun mekanisme penurunan nyeri terapi bekam basah belum jelas. Peregangan dan tusukan pada terapi bekam basah menimbulkan stres pada sel. Sel yang mengalami stres mengekspresikan HSP 70 dan reseptor opioid mu. Penelitian ini bertujuan membuktikan korelasi peningkatan ekspresi HSP 70 dan peningkatan reseptor opioid mu pasca terapi bekam basah. Metode: Jenis penelitian ini adalah penelitian eksperimental dengan rancangan randomized control group post test only design. Dua puluh empat tikus jenis Wistar (Rattus norvegicus) secara random dibagi menjadi tiga kelompok yang masing-masing terdiri dari 8 ekor tikus yaitu kelompok kontrol negatif (tikus normal), kelompok induksi nyeri dengan Complete Freund's Adjuvant (CFA) saja (kontrol positif) dan kelompok yang diberi induksi nyeri dan terapi bekam basah (10 tusukan dan tekanan negatif: - $200 \mathrm{mmHg}, 5 \mathrm{menit}$ ). Sampel diambil dari kulit dan dilakukan pemeriksaan imunohistokimia dengan antibodi monoklonal anti reseptor opioid mu. Waktu reaksi ambang nyeri diukur memakai hot-plate. Data dianalisa dengan Anova oneway dan Pearson Correlation dengan menggunakan SPSS versi 17. Hasil: Penelitian ini menunjukkan bahwa terdapat peningkatan ekspresi HSP 70 $(20,25 \pm 3,53$; $\mathrm{p}<0.05)$ dibandingkan kelompok kontrol positif $(10,50 \pm 2,44 ; \mathrm{p}<0,05)$ dan peningkatan ekspresi reseptor opioid mu $(21,00$ $\pm 6,34 ; \mathrm{p}<0.05)$ dibandingkan kelompok kontrol positif $(4,25 \pm 3,58 ; \mathrm{p}<0.05)$. Terdapat peningkatan waktu reaksi ambang nyeri $(22,81 \pm 6,34 ; \mathrm{p}<0,05)$ dibandingkan kontrol positif $(11,78 \pm 3,56)$. Terdapat korelasi antara peningkatan ekspresi HSP 70 dan peningkatan reseptor opioid mu $(\beta=0.893 ; \mathrm{p}=0.000)$ dan ada korelasi antara peningkatan reseptor opioid mu dengan waktu reaksi ambang nyeri $(\beta=0.713 ; p=0.002)$. Diskusi: Terapi bekam basah meningkatkan ekspresi HSP 70 , reseptor opioid mu dan waktu reaksi ambang nyeri.
\end{abstract}

Kata Kunci: Ekspresi HSP 70, Ekspresi Opioid, Penurunan Nyeri, Bekam Basah

\begin{abstract}
Introduction: Wet cupping therapy widely used to reduce the pain, but the mechanisms of pain reduction on wet cuppig therapy is unclear. Stretching and punctures on wet cupping therapy cause stress on the cell. Cells that are stressed express HSP 70 and mu opioid receptors. This study aims to prove the correlation increased expression of HSP 70 and an increase in post-mu opioid receptor wet cupping therapy. Methods: The study is an experimental research design with randomized control group post-test only design. Twenty-four rats type Wistar (Rattus norvegicus) were randomly divided into three groups, each consisting of eight mice are negative control group (normal mice), group induction of pain with Complete Freund's Adjuvant (CFA) alone (positive control) and group by induction of pain and bekam basah therapy (10 puncture and negative pressure: - $200 \mathrm{mmHg}, 5$ minutes). Samples were taken from the skin and immunohistochemical examination with the monoclonal antibody anti mu opioid receptors. The reaction time pain threshold measured using a hot-plate. Data were analyzed by oneway ANOVA and Pearson Correlation using SPSS version 17. Results: This study shows that there is an increased expression of HSP $70(P<0.05)$ compared to the positive control group $(p<0.05)$ and increased expression of mu opioid receptors $(p<0.05)$ compared to the positive control group $(p<0.05)$. There is an increased pain threshold reaction time $(p<0.05)$ compared to the positive controls $(11.78 \pm 3.56)$. There is a correlation between an increased expression of HSP 70 and an increase in mu opioid receptor $(\beta=0893 ; p=0.000)$ and there was a correlation between the increase in mu opioid receptor with a reaction time of pain threshold $(\beta=0713 ; p=0.002)$. Discussion: Wet cupping therapy increase HSP 70 expression, opioid mu receptor, and decrease pain level.
\end{abstract}

Keywords: HSP 70, mu opioid receptors, wet cupping therapy

\section{PENDAHULUAN}

Bangsa Indonesia mempunyai berbagai terapi alternatif, salah satu dari terapi alternatif tersebut adalah terapi bekam. Masyarakat menggunakan terapi bekam untuk menyembuhkan sakit kepala, pegal linu, nyeri sendi, rematik, masuk angin (Kasmui 2012). Terapi bekam dikenal dua macam metode yaitu terapi bekam kering dan terapi bekam basah. Terapi bekam kering adalah metode terapi dimana kulit dilakukan pengekopan atau pemberian tekanan negatif tanpa tusukan, sedangkan terapi bekam basah adalah metoda terapi dimana darah dikeluarkan dari tubuh melalui permukaan kulit dengan cara penusukan pada kulit kemudian dilakukan pengekopan. Masyarakat menggunakan terapi bekam kering untuk nyeri yang ringan, sedangkan terapi bekam basah digunakan bila nyeri berat. 
Meskipun telah dikenal manusia sejak ribuan tahun yang lalu, sampai saat ini penelitian terapi bekam sangat terbatas (DK 2010) Pada dekade terakhir dilaporkan terapi bekam basah efektif untuk menurunkan nyeri kepala (Ahmadi et al. 2008), brachialgia parasthetica nocturna (Lutdke, et al. 2006), carpal tunnel syndrome ( Michalsen et al. 2009) nyeri punggung bawah (Farhadi et al, 2009). Mekanisme penurunan nyeri inflamasi terapi bekam basah sampai saat ini belum jelas.

Nyeri merupakan keluhan utama yang paling sering dijumpai dalam praktek dokter sehari-hari (Smith BH 1999) Penelitian tentang nyeri di 15 negara di Eropa dilaporkan bahwa prevalensi nyeri kronis adalah sebesar 19\% ( Breivik et al. 2006) Prevalensi nyeri kronis di Amerika Serikat sebesar 30,7\% (Johanes et al. 2010) , sedangkan di Hong Kong sebesar 34,9\% (Wong dan Feilding 2011). Menurut World Health Organization (WHO), prevalensi nyeri kronis di negara sedang berkembang 41 $\%$ (Croft et al. 2010). Survei pada 4683 orang desa dan 1071 orang kota di Jawa Tengah, didapatkan angka kejadian nyeri $23,6 \%$ di desa dan 31,3\% di kota (Darmawan et al., 1992).

Dampak nyeri kronis mengganggu kehidupan sehari-hari. Nyeri kronis berdampak pada gangguan tidur, aktifitas olah raga, berjalan, melakukan pekerjaan rumah tangga, menghadiri kegiatan sosial, kehidupan seksual dan kemandirian pola hidup ( Breivik et al., 2006), kualitas hidup (Katz 2002) dan pekerjaan (Smith et al. 2001). Di Amerika Serikat, dampak ekonomi nyeri kronis diperkirakan senilai 61, 2 milyard dollar Amerika setiap tahun yang disebabkan waktu produktif yang hilang (Reyes-Gibby C 2008).

Saat ini penanganan nyeri kronis meliputi terapi farmakologi, non farmakologi dan terapi intervensi. Pemberian NSAIDs berkepanjangan menimbulkan komplikasi (Brattwall et al., 2010). Gejala yang muncul akibat komplikasi NSAIDs antara lain dispepsia, tukak lambung, dan perdarahan lambung ( Fujimori et al. 2010).

Analgesik opioid adalah obat yang paling efektif dan sering digunakan untuk mengurangi nyeri sedang sampai berat. Salah satu opioid endogen adalah $\beta$-endorfin yang paling utama dikode oleh proopiomelanocortin (POMC) (Koneru. A et al. 2009). Opioid menghambat produksi L-glutamat di terminal sentral aferen primer pada kornu dorsal medula spinalis dan juga menghambat timbulnya potensial aksi pada terminal perifer aferen primer sehingga transmisi saraf tidak terjadi yang berakibat nyeri menurun. Hipotesa penelitian ini adalah penurunan nyeri inflamasi disebabkan ekspresi reseptor opioid $\mathrm{mu}$, mengingat sel yang mengalami stres merangsang hipofise mengekspresikan proopiomelanocortin yang memicu $\beta$-endorfin. Reseptor utama $\beta$-endorfin adalah reseptor opioid mu.

\section{METODE}

Jenis penelitian yang digunakan adalah penelitian eksperimental dengan rancangan penelitian post test only control group design. Kelaikan etik diperoleh dari Fakultas Kedokteran Hewan Universitas Airlangga. Dua puluh empat tikus putih jenis Wistar (Rattus norvegicus) secara random dibagi menjadi tiga kelompok yang masing-masing kelompok terdiri dari 8 ekor tikus putih. Kelompok pertama adalah kelompok kontrol negatif yaitu tikus yang tidak mendapat apa-apa. Kelompok kedua adalah kelompok kontrol positif yaitu tikus yang hanya mendapat induksi nyeri Complete Freund's Adjuvant (CFA), sedangkan kelompok ketiga adalah kelompok perlakuan yaitu selain diinduksi nyeri juga dilakukan terapi bekam basah. Penelitian dilakukan di beberapa laboratorium yang berbeda. Pembuatan jaringan model dilakukan di Laboratorium Departemen Farmakognisi dan Sitokimia Fakultas Farmasi Universitas Airlangga. Pembuatan preparat dan foto dilakukan di Laboratorium Patologi Anatomi Fakultas Kedokteran Universitas Airlangga. Pewarnaan teknik imunohistokimia dan penghitungan dilakukan di Laboratorium Biomolekuler dan Biokimia Fakultas Kedokteran Universitas Brawijaya.

Model hewan nyeri inflamasi yaitu tikus putih diinjeksi $100 \mu \mathrm{L}$ CFA pada permukaan plantar kaki ipsilateral. Empat puluh delapan jam setelah induksi nyeri, model hewan nyeri inflamasi yang terjadi dilakuan terapi bekam kering pada kelompok perlakuan. Terapi bekam basah adalah pemberian tusukan dengan lancet kemudian diberi tekanan negatif sebesar - $200 \mathrm{mmHg}$ pada kulit punggung bilateral selama 5 menit. Dua puluh empat jam setelah terapi bekam basah, hewan coba dikorbankan dan diambil jaringan medula spinalis.

Ekspresi reseptor opioid mu adalah penilaian positif dengan teknik imunohistokimia menggunakan 
antibodi monoklonal anti reseptor opioid mu. Penilaian dilakukan secara kuantitatif visual dengan mikroskop cahaya dengan pembesaran 1000 kali terhadap sel saraf di medula spinalis yang mengekspresikan reseptor opioid mu. Penghitungan dilakukan terhadap sel saraf yang imunoreaktif tercat coklat pada sitoplasma sel saraf pada dua puluh lapangan pandang yang berbeda. Hasil setiap perhitungan ditulis pada lembar kerja dan diambil nilai rata-rata per lapang pandang. Parameter nyeri diukur memakai alat hot plate (Ugo Basile) dengan suhu $51{ }^{\circ} \mathrm{C}$ berdasarkan waktu reaksi ambang nyeri yaitu waktu mulai kaki tikus menginjak hot plate sampai tikus menjilat kaki atau melompat. Data dianalisa dengan menggunakan Anova Oneway, BrownForsythe, Gomes-Howell dan Pearson Correlation.

\section{HASIL}

\section{Ekspresi HSP 70}

Hasil pemeriksaan preparat dengan teknik imunohistokimia menunjukkan peningkatan jumlah sel keratinosit yang mengekspresi HSP 70, ditandai dengan reaksi warna coklat terhadap antibodi anti HSP 70 pada kelompok terapi bekam basah dibandingkan kelompok kontrol (gambar 1).

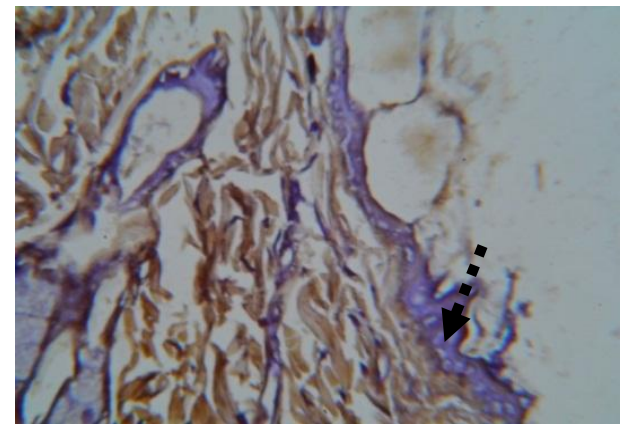

(A)

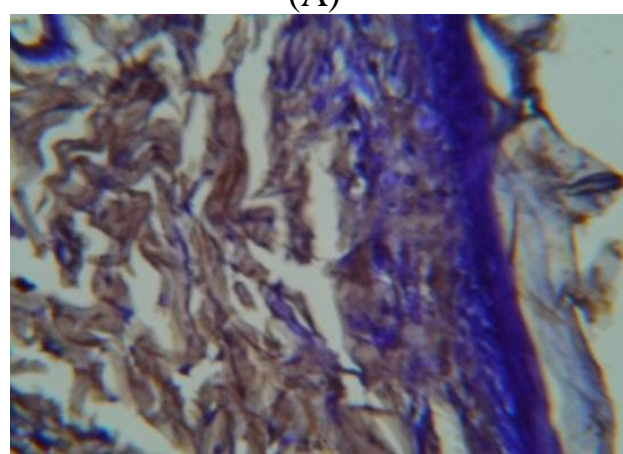

(B)

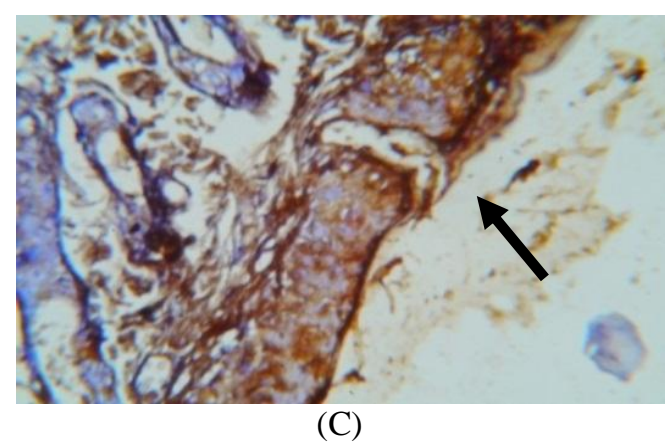

Gambar 1. Sayatan jaringan kulit tikus putih dengan menggunakan antibodi monoklonal anti HSP 70 pada kelompok kontrol negatif (A), kelompok kontrol positif (B) dan kelompok terapi bekam basah(C).

Pembesaran $400 \mathrm{x}$ dengan mikroskop cahaya dan kamera Merk Olympic. Negatif : sel keratinosit tidak memberikan reaksi warna coklat. Positif : sel keratinosit memberi reaksi warna coklat terhadap antibodi monoklonal anti $\beta$-endorfin.

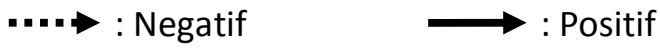

Hasil penghitungan sel keratinosit yang mengekspresikan HSP 70 pada kelompok kontrol negatif, kelompok kontrol positif, kelompok terapi bekam kering dan kelompok terapi bekam basah ditunjukkan pada tabel 1 .

Tabel 1. Rerata dan simpang baku ekspresi HSP 70 pada sel keratinosit masing-masing kelompok.

\begin{tabular}{|c|c|c|c|c|c|}
\hline \multirow[t]{2}{*}{ Kelompok } & \multicolumn{4}{|c|}{$\begin{array}{l}\text { HSP } 70 \text { (jml. sel/ lap. pandang/ } \\
\text { pemb.1000x) }\end{array}$} & \multirow{2}{*}{$\begin{array}{c}\text { Anova } \\
\text { Oneway } \\
\text { (p) }\end{array}$} \\
\hline & $\mathrm{X}$ & SD & Min & Maks & \\
\hline $\begin{array}{l}\text { Kontrol } \\
\text { negatif }\end{array}$ & $5,62^{\mathrm{a}}$ & 1,84 & 3 & 8 & \multirow{3}{*}{$\begin{array}{c}\mathrm{p}< \\
0,001\end{array}$} \\
\hline $\begin{array}{l}\text { Kontrol } \\
\text { positif }\end{array}$ & $10,50^{b}$ & 2,44 & 6 & 14 & \\
\hline $\begin{array}{l}\text { Terapi } \\
\text { bekam } \\
\text { basah }\end{array}$ & $20,25^{c}$ & 3,53 & 13 & 24 & \\
\hline
\end{tabular}

Keterangan : Signifikan pada $\alpha=0,05$. Superscript yang berbeda menunjukkan ada perbedaan antar kelompok (berdasarkan LSD).

Uji normalitas dengan KolmogorovSmirnov ekspresi HSP 70 pada semua kelompok menunjukkan data berdistribusi normal ( $\mathrm{p}>0,05)$. Uji homogenitas dengan Levene's test menunjukkan ekspresi HSP 70 antar kelompok mempunyai variansi yang homogen ( $\mathrm{p}>0,05)$. Pengujian dengan Anova Oneway antar kelompok perlakuan 
menunjukkan perbedaan yang signifikan ( $\mathrm{p}<$ 0,05). Berdasarkan analisis data diatas dapat disimpulkan terapi bekam basah meningkatkan ekspresi HSP 70 dibandingkan kontrol.

\section{Ekspresi Reseptor Opioid Mu}

Hasil pemeriksaan preparat dengan teknik imunohistokimia menunjukkan peningkatan jumlah sel saraf di medula spinalis yang mengekspresi reseptor opioid mu yang memberi reaksi warna coklat terhadap antibodi anti resept oropioid mu pada kelompok terapi bekam basah dibandingkan kelompok kontrol (gambar 2).

A

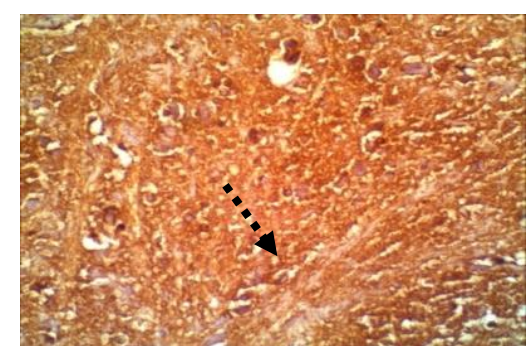

B

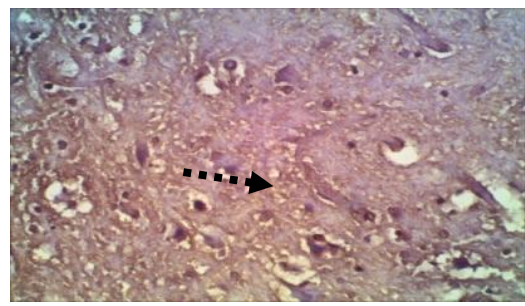

C

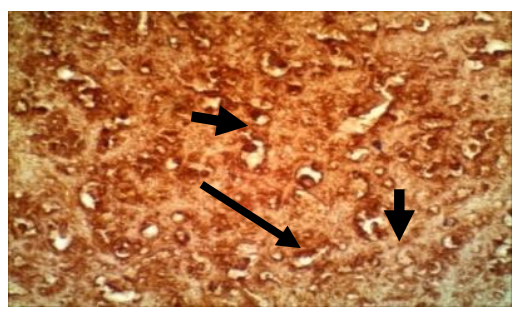

Gambar 2. Sayatan jaringan medula spinalis tikus putih dengan menggunakan antibodi monoklonal anti reseptor opioid mu pada kelompok kontrol negatif (A), kelompok kontrol positif (B) dan kelompok terapi bekam basah (C).

Pembesaran $400 \mathrm{x}$ dengan mikroskop cahaya dan kamera Merk Olympic. Negatif : sel keratinosit tidak memberikan reaksi warna coklat. Positif : sel keratinosit memberi reaksi warna coklat terhadap antibodi monoklonal anti $\beta$-endorfin.

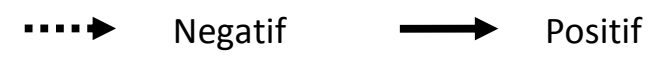

Uji normalitas dengan dengan Kolmogorov-Smirnov ekspresi reseptor opioid mu pada semua kelompok menunjukkan data berdistribusi normal ( $\mathrm{p}>0,05)$. Uji homogenitas dengan Levene's test menunjukkan ekspresi reseptor opioid mu antar kelompok mempunyai varians yang homogen $(\mathrm{p}>0,05)$. Pengujian dengan Anova Oneway antar kelompok perlakuan menunjukkan perbedaan yang signifikan $(p<0,05)$.

Hasil uji LSD menunjukkan bahwa ada perbedaan antara kelompok kontrol negatif dan kelompok kontrol positif. Antara kelompok terapi bekam basah terdapat perbedaan yang bermakna dengan kelompok kontrol positif.

Tabel 2. Rerata dan simpang baku ekspresi reseptor opioid mu pada sel saraf masing-masing kelompok.

\begin{tabular}{|c|c|c|c|c|c|}
\hline \multirow[t]{2}{*}{ Kelompok } & \multicolumn{4}{|c|}{$\begin{array}{l}\text { Reseptor opioid mu (jml. sel/ } \\
\text { lap. pandang/ pemb. } 1000 \mathrm{x})\end{array}$} & \multirow{2}{*}{$\begin{array}{c}\text { Anova } \\
\text { Oneway } \\
\text { (p) }\end{array}$} \\
\hline & $\mathrm{X}$ & SD & Min & Maks & \\
\hline $\begin{array}{l}\text { Kontrol } \\
\text { negatif }\end{array}$ & $10,62^{a}$ & 3,92 & 3 & 16 & \multirow{3}{*}{$\begin{array}{c}\mathrm{p}< \\
0,001\end{array}$} \\
\hline $\begin{array}{l}\text { Kontrol } \\
\text { positif }\end{array}$ & $4,25^{b}$ & 3,58 & 7,5 & 18 & \\
\hline $\begin{array}{l}\text { Terapi } \\
\text { bekam } \\
\text { basah }\end{array}$ & $21,00^{c}$ & 6,34 & 14,30 & 30 & \\
\hline
\end{tabular}

\section{Waktu Reaksi Ambang Nyeri}

Uji normalitas dengan dengan KolmogorovSmirnov waktu reaksi ambang nyeri pada semua kelompok menunjukkan data berdistribusi normal ( $p$ > 0,05). Uji homogenitas dengan Levene's test menunjukkan waktu reaksi ambang nyeri antar kelompok mempunyai variansi yang tidak homogen $(\mathrm{p}<0,05)$. Karena Levene's test menunjukkan hasil yang tidak homogen maka dilakukan uji BrownForsythe. Uji Brown-Forsythe menunjukkan hasil yang signifikan $(\mathrm{p}<0,05)$ sehingga perhitungan antar kelompok digunakan uji Games-Howell. Hasil uji Games-Howell menunjukkan tidak ada perbedaan antara kelompok kontrol negatif dan kontrol positif $(\mathrm{p}=0,764)$. Terdapat perbedaan antara kelompok kontrol negatif dan terapi bekam basah $(0,002)$. Terdapat perbedaan antara kelompok kontrol positif dan terapi bekam basah $(0,003)$. Berdasarkan analisis data di atas terapi bekam basah meningkatkan waktu reaksi ambang nyeri.

\section{Korelasi ekspresi HSP 70, reseptor opioid mu dan waktu reaksi ambang nyeri}

Uji korelasi Pearson menunjukkan terdapat korelasi antara ekspresi HSP 70 dan 
ekspresi reseptor opioid $\mathrm{mu}(\beta=0,687 ; \mathrm{p}=$ 0,000). Terdapat korelasi antara ekspresi reseptor opioid mu dengan waktu reaksi ambang nyeri $((\beta=0,617 ; p=0,001)$.

\section{PEMBAHASAN}

Penelitian ini menunjukkan terapi bekam basah meningkatkan ekspresi HSP 70, reseptor opioid mu dan waktu reaksi ambang nyeri. Pada penelitian ini terapi bekam basah meningkatkan waktu reaksi ambang nyeri yang artinya bahwa hewan coba lebih tahan terhadap paparan panas. Penelitian efek terapi bekam basah pada hewan coba belum pernah ada. Penelitian pada manusia menunjukkan bahwa terapi bekam basah efektif untuk menurunkan nyeri kepala (Ahmadi et al. 2008), brachialgia parasthetica nocturna (Ludtke et al. 2006), carpal tunnel syndrome (Michalsen. A et al. 2009), nyeri punggung bawah (Farhadi et al. 2009). Peningkatan ekspresi HSP 70 berhubungan dengan peningkatan ekspresi $\beta$-endorfin .

Tusukan pada kulit menyebabkan membran sel keratinosit rusak. Kerusakan jaringan akibat tusukan menimbulkan reaksi inflamasi yaitu pengeluaran mediator-mediator inflamasi antara lain bradikinin, prostaglandin, leukotrien, serotonin, histamin, substansi $\mathrm{P}$, tromboksan, platelet-activating factor (PAF), adenosin dan adenosine triphosphat (ATP), proton dan radikal bebas (Dougherly dan Raja, 2011). Shah dan kawan-kawan menunjukkan bahwa prostaglandin E2 memicu ekspresi HSP 70.

Pada mamalia, aktivasi hypothalamic-pituitaryadrenal (HPA) axis merupakan respon endokrin utama terhadap stres dan ditandai peningkatan corticotopin releasing hormon (CRH). Pada sel corticotrophs hipofise, CRH berikatan dengan reseptor CRHR1 menstimulasi transkripsi gen proopiomelanocortin (POMC). Proopiomelanocortin merupakan progenitor adrenocotropic hormone (ACTH) dan $\beta$-endorfin (Slominski et al., 2000). Meer dan kawan-kawan (1996) melakukan penelitian pada tikus yang diinduksi IL- $1 \beta$, TNF- $\alpha$ dan IL-6 dan dilaporkan bahwa IL-1 $\beta$, IL-6 dan TNF- $\alpha$ memicu ekspresi CRH, dimana IL-1 $\beta$ lebih kuat memicu ekspresi CRH dibandingkan IL-6 dan TNF- $\alpha$. Hasil penelitian melaporkan bahwa induksi NFkB pada sel corticotrophs hipofise memicu gen POMC melalui CRH (Karalis et al. 2004). Hasil penelitian didapatkan bahwa bahwa NFkB secara langsung mengikat gen POMC untuk menstimulasi transkripsi POMC (Jang PG, Namkoong C, Kang GM, Hur MW, Kim SW, Kim GH, Kang Y, Jeon MJ, Kim EH, Lee MS, Karin M, Baik JH, Park JY, Lee KU 2010). Hasil penelitian didapatkan bahwa induksi IL-1 $\beta$ pada sel hipofise menstimulasi ekspresi $\beta$-endorfin namun tergantung dosis dan waktu (Fagarasan, et al. 1989). Pada 12 jam pasca induksi Il-1 $\beta$ tidak terjadi sekresi $\beta$-endorfin, baru setelah 24 jam $\beta$-endorfin tersekresi. Pada dosis $1 \mathrm{pM}$ IL$1 \beta$ tidak terjadi sekresi $\beta$-endorfin, sedangkan dosis $1 \mathrm{nM}$ IL-1 $\beta$ terjadi sekresi $\beta$-endorfin (Fagarasan et al. 1989). Hasil penelitian dilaporkan bahwa $\beta$-endorfin mengaktifkan reseptor opioid $\mathrm{mu}$ (Gharagozlou $\mathrm{P}$ et al. 2006).

Pada uji korelasi Pearson menunjukkan adanya korelasi antara peningkatan ekspresi HSP 70 dengan peningkatan reseptor opioid mu. Peneliti menduga regangan dan tusukan menyebabkan HSP 70 terekspresi sehingga memicu ekspresi reseptor opioid mu. Pada uji korelasi juga ditunjukkan adanya korelasi antara peningkatan ekspresi reseptor opioid mu dengan waktu reaksi ambang nyeri.

\section{SIMPULAN DAN SARAN}

\section{Simpulan}

Terjadi peningkatan ekspresi HSP 70 dan reseptor opioid mu pada terapi bekam basah. Terdapat korelasi antara peningkatan ekspresi HSP 70 dan peningkatan ekspresi reseptor opioid mu. Terdapat korelasi antara peningkatan reseptor opioid mu dengan peningkatan waktu reaksi ambang nyeri.

\section{Saran}

Terapi bekam basah dapat digunakan sebagai alternatif terapi untuk menurunkan tingkat nyeri, namun uji coba pada manusia masih perlu diteliti lebih lanjut.

\section{KEPUSTAKAAN}

A, A., DC, S. \& M, R., 2008. The efficacy of Wet-Cupping in the treatment of Tension and Migraine Headache. The American Journal of Chinese Medicine, pp.37-44.

A, K., S, S. \& S, R., 2009. Endogenous Opioids: Their Physiological Role and Receptors. Global Journal of Pharmacology, p.3( 3): 149-153.

A, M. et al., 2009. Effects of Traditional Cupping Therapy in Patients with Carpal Tunnel Syndrome. The Journal of Pain, 
p.10: $1-8$.

BH, S. et al., 2001. The Impact of Chronic Pain in the Community. Family Practice,

CB, J. et al., 2010. The Prevalence of Chronic Pain in United States Adult: Result of Internet=Based Survey. The Journal of Pain, p.11: 1230-1239.

DK, O., 2010. Hijama, or cupping. Greek Medicine.net. Available at: http://www.greekmedicine.net/therapies/ Hijam_or_Cupping.html [Accessed November 10, 2013].

Gharagozlou P et al., 2006. Characterization of Endogenous Peptides at $\mathrm{Mu}$, Delta and Kappa Opioid Receptors. In Proceedings of the Western Pharmacology Society. p. 49: 109-113.

H, B. et al., Survey of chronic pain in Europe: Prevalence, impact on daily life, and treatment. European Journal of Pain, pp.287-333.

J, D. et al., Epidemiology of rheumatic disease in rural and urban populations in Indonesia : a World Health Organization League Against Rheumatism COPCORD study, stage 1, phase 2. Annals of the Rheumatism Diseases,

Jang PG, Namkoong C, Kang GM, Hur MW, Kim SW, Kim GH, Kang Y, Jeon MJ, Kim EH, Lee MS, Karin M, Baik JH, Park JY, Lee KU, K.Y. and K.M., 2010. NF-kB Activation in Hypothalamic Proopiomelanocortin Neurons Is Essential in Illness- and Leptin-Induced Anorexia. The Journal of Biological Chemistry, p.285(13): 9706-97115.

K, F. et al., 2009. The effectiveness of wetcupping for nonspecific low back pain in Iran. Complementary Therapies in Medicine. , p.17: 9-15.

Kasmui, 2012. Bekam Pengobatan menurut
Sunnah Nabi. Available at: http://www.archive.org/details/BEKAM_ Pengobatan_Menurut_Sunnah_Nabi.

KP, K. et al., 2004. NF-kB Participates in the Corticotropin-releasing, Hormoneinduced Regulation of the Pituitary Proopiomelanocortin Gene. The Journal of Biological Chemistry, p.279(12): 10837-10840.

MO, F., R, E. \& J, A., 1989. Interleukin-1 potentiates the secretion of $\beta$-endorphin induced by secretagogues in amouse pituitary cell line (AtT-20). In Proceedings of the National Academy of Science. p. 86: 2070-2073.

N, K., 2002. The Impact of Pain Management on Quality of Life. Journal of Pain and Symptom Management, p.24: S38-S47.

P, C., FM, B. \& D, W., 2010. The global occurence of chronic pain. In: Croft P, Blyth FM and Windt D eds, Chronic Pain Epidemiology, Oxford University Press.

R, L. et al., 2006. Brachialgia paraesthetica nocturna can be relieved by wet cupping. Complementary Therapies in Medicine,

Reyes-Gibby C, T.-V.I. and C.R., 2008. Epidemiology of chronic pain: classical to molecular approaches to understanding the epidemiology of pain. In (Wilson PR, Watson PJ, Haythornthwaite JA and Jensen TS, eds). Chronic Pa., London: Hodder Arnold, pp.

S, F., K, G. \& C, S., 2010. A review of AntiInflammatory Drug-Induces Gastrointestinal Injury. Pharmaceuticals, Smith BH, H.J. and C.W., 1999. Chronic pain in primary care. Famiy Practice,

WS, W. \& R, F., 2011. Prevalence and Characteristics of Chronic Pain in the General Population of Hong Kong. The Journal of Pain, p.12: 236-245. 